\title{
PERSEPSI PEMUDA TERHADAP KEGIATAN USAHATANI KELAPA DI DESA KAUDITAN II KECAMATAN KAUDITAN
}

\author{
Jouke Adelheid Punuh \\ Joachim Noch Karel Dumais \\ Melsje Yellie Memah
}

\begin{tabular}{ll}
\hline Naskah diterima melalui Website Jurnal Ilmiah agrisosioekonomi@unsrat.ac.id & $:$ Kamis, 19 Desember 2019 \\
Disetujui diterbitkan & :Kamis, 09 Januari 2020 \\
\hline
\end{tabular}

\begin{abstract}
The objective of this research to find out how young people's perceptions of knowing and doing coconut farming business activities in Kauditan II Village, Kauditan Sub-district, North Minahasa Regency. The research conducted for six months, namely July to December 2019. The data used in this study are primary and secondary data. The research was carried out in Kauditan II Village, Kauditan District, North Minahasa Regency. The choice of location in this study was chosen based on the consideration that the village has coconut farmland. The research lasted for six months, from July to December 2019. Sampling was carried out deliberately on 37 young men whose parents engaged in coconut. The data needed in this study are primary data and secondary data. Primary data collected through interviews is carried out using a list of questions. Secondary data was obtained through documents and literature research results as well as data and information available at the Kauditan II Village Office. The data analysis technique used is the analysis and descriptive techniques using a Likert Scale measurement. The results showed that the youth agreed to do and understand the activities of coconut farming. The statement of youth to know postharvest tends to be higher, that is to agree because postharvest work is considered easier than other farming activities while the lowest score of the statement of youth wants to harvest on coconut trees because young people do not want to do coconut climbing activities that require special techniques. ${ }^{*}$ prm*
\end{abstract}

Keywords: Perception, Youth, Coconut, Likert Scale

\begin{abstract}
ABSTRAK
Penelitian ini bertujuan mengetahui bagaimana persepsi pemuda untuk mengetahui dan melakukan kegiatan usaha tani kelapa di Desa Kauditan II, Kecamatan Kauditan, Kabupaten Minahasa Utara. Penelitian berlangsung selama enam bulan yaitu bulan Juli sampai bulan Desember 2019. Penelitian ini di laksanakan di Desa Kauditan II Kecamatan Kauditan, Kabupaten Minahasa Utara. Pemilihan lokasi dalam penelitian ini dipilih secara sengaja berdasarkan pertimbangan bahwa desa tersebut memiliki lahan pertanian kelapa. Waktu penelitian berlangsung selama enam bulan yaitu bulan Juli sampai bulan Desember 2019. Pengambilan sampel dilakukan secara sengaja pada 37 pemuda yang orang tuanya berusahatani kelapa. Data yang diperlukan dalam penelitian ini yaitu data primer dan data sekunder. Data primer dikumpulkan melalui wawancara dilakukan dengan menggunakan daftar pertanyaan yang telah disiapkan terlebih dahulu. Data sekunder diperoleh melalui dokumen dan hasil penelitian kepustakaan serta data dan informasi yang ada di Kantor Desa Kauditan II Kecamatan Kauditan. Teknik analisis data yang digunakan adalah teknik analisis dan deskriptif dengan menggunakan pengukuran Skala Likert. Hasil penelitian menunjukkan bahwa para pemuda setuju untuk mengetahui dan ingin melakukan kegiatan usahatani kelapa. Pernyataan pemuda untuk mengetahui pascapanen cenderung lebih tinggi yaitu setuju karena pekerjaan pascapanen dianggap lebih mudah dibandingkan dengan kegiatan usahatani lainnya. sedangkan skor terendah dari pernyataan pemuda ingin melakukan panen pada tanaman kelapa karena pemuda tidak ingin melakukan kegiatan panjat kelapa yang membutuhkan teknik khusus untuk pemanjatan pohon kelapa. ${ }^{*}$ eprm*
\end{abstract}

Kata kunci: Persepsi, Pemuda, Kelapa, Skala Likert

Agrisosioekonomi: 


\section{PENDAHULUAN}

\section{Latar Belakang}

Usaha tani merupakan satu-satunya ujung tombak pembangunan nasional yang mempunyai peran penting. Upaya mewujudkan pembangunan nasional bidang pertanian (agribisnis) masa mendatang merupakan sejauh mungkin mengatasi masalah dan kendala yang sampai sejauh ini belum mampu di selesaikan secara tuntas sehingga memerlukan perhatian yang lebih serius. Satu hal yang sangat kritis adalah bahwa meningkatnya produksi pertanian (agribisnis) atau output selama ini belum disertai dengan meningkatnya pendapatan dan kesejahteraan petani secara signifikan dalam usaha taninya.

Persepsi yang dimiliki oleh pemuda di Desa Kauditan II Kecamatan Kauditan saat ini, secara tidak langsung berpengaruh terhadap menurunnya minat pemuda untuk bekerja di bidang pertanian. Minat diartikan sebagai salah satu aspek psikis yang dapat mendorong pemuda untuk mencapai sebuah tujuan, yakni mencukupi kebutuhannya. Pemuda yang memiliki minat tinggi untuk bekerja di bidang pertanian, akan cenderung memiliki perasaan senang terhadap bidang pertanian namun sebaliknya, apabila pekerjaan pada bidang pertanian tidak mampu menimbulkan rasa senang pada diri pemuda, maka pemuda tidak akan memiliki minat untuk bekerja di bidang pertanian. Oleh karena itu, tinggi rendahnya minat pemuda untuk bekerja di bidang pertanian, diyakini akan dipengaruhi oleh seberapa baik persepsi pemuda terhadap kegiatan usahatani kelapa.

Desa Kauditan merupakan daerah penghasil kelapa terbanyak dengan capaian produksi masing-masing 537.777 ton dan 608.819 ton pada tahun 2012 (BPS,2012). Berdasarkan data tersebut dapat disimpulkan bahwa pekerja masih di dominasi oleh petani kelapa. Data dari kantor Desa Kauditan II pada tahun 2019 merupakan salah satu desa yang berada diwilayah Kecamatan Kauditan dan tepatnya berada di ibu kota Kecamatan Kauditan. di Desa Kauditan II memiliki luas tanah 962 ha sebagai lahan pertanian dan tingkat kesuburan tanah yang cukup baik, dan memiliki jumlah petani 219 orang dari jumlah angkatan kerja keseluruhan 1,275 orang, dengan jumlah pemuda 662 orang, (Kantor Desa Kauditan II,2019).

\section{Pengertian Persepsi}

Kehidupan bermasyarakat tidak akan lepas dari persepsi masyarakat itu sendiri. Persepsi merupakan tanggapan atau penerimaan langsung dari seseorang. Menurut Jalaludin Rackhmat (2011) dalam Heriyanto (2014) persepsi merupakan pengalaman tentang obyek, peristiwa, atau hubungan-hubungan yang diperoleh dengan menyimpulkan informasi dan menafsirkan pesan.

Sedangkan menurut Bimo Walgito (2002) dalam Heriyanto (2014) persepsi merupakan suatu proses yang di dahului penginderaan yaitu proses stimulus oleh individu melalui proses sensoris. Namun proses itu tidak berhenti begitu saja, melainkan stimulus tersebut diteruskan dan diproses selanjutnya merupakan proses persepsi.

Persepsi adalah proses dimana individu memilih, mengorganisasikan, dan mengartikan stimulus yang diterima melalui alat inderanya menjadi suatu makna Soloman (2013) dalam Setiawan (2010). Menurut Suharto (2005) dalam Rachman (2013) persepsi merupakan aktivitas mengindera, mengintergrasikan dan memberikan penilaian pada objek objek fisik dan stimulus sosial, dan penginderaan tersebut tergantung pada stimulus fisik stimulus sosial yang ada di lingkungannya.

\section{Faktor-faktor Yang Mempengaruhi Persepsi \\ Menurut Gibson (1989), dkk} (www.duniapsikologi.com) menyatakan bahwa, ada 2 faktor yang mempengaruhi persepsi, faktor tersebut adalah:

\section{Faktor Internal}

Faktor-faktor yang terdapat dalam diri individu, yang mencakup beberapa hal antara lain:
a. Fisiologis
b. Perhatian
c Minat
d. Kebutuhan yang searah
e. Pengalaman dan ingatan, dan
f. Suasana hati.

\section{Faktor Eksternal}

Merupakan karakteristik dari lingkungan dan obyek-obyek yang terlibat di dalamnya. Elemenelemen tersebut dapat mengubah sudut pandang seseorang terhadap dunia sekitarnya dan mempengaruhi bagaimana seseoarang merasakannya atau menerimanya. Sementara itu faktor-faktor eksternal yang mempengaruhi persepsi yaitu 
a. Ukuran dan penempatan dari obyek atau stimulus.

b. Warna dari obyek-obyek.

c. Keunikan dan kekontrasan stimulus.

d. Intensitas dan kekuatan dari stimulus.

e. Motion atau gerakan.

\section{Usahatani}

Usahatani (farm) adalah organisasi dari alam (lahan), tenaga kerja, dan modal yang ditujuhkan kepada produksi di lapangan pertanian. Organisasi tersebut ketatalaksanaan-nya berdiri sendiri dan sengaja diusahakan oleh seseorang atau sekumpulan orang sebagai pengelolanya. Dengan istilah usahatani di atas telah mencakup pengertian yang luas, dari bentuk yang paling sederhana sampai yang paling modern, Firdaus Muhammad (2015).

Soekartawi dalam Warsana (2007) mengatakan bahwa pengelolaan usahatani yang efisien akan mendatangkan pendapatan yang positif atau suatu keuntungan, usahatani yang tidak efisien akan mendatangkan suatu kerugian. Usahatani yang efisien adalah usahatani yang produktivitasnya tinggi. Ini bisa dicapai kalau manajemen pertaniannya baik. Dalam faktor-faktor produksi dibedakan menjadi dua kelompok:

a. Faktor biologi, seperti lahan pertanian dengan macam-macam tingkat kesuburan, benih, varitas pupuk, obat-obatan, gulma.

b. Faktor sosial ekonomi, seperti biaya produksi, harga, tenaga kerja, tingkat pendidikan, status pertanian, tersedianya kredit dan sebagainya Soekarwati dalam Warsana (2007).

\section{Pemuda}

Rohmad (1998) dalam Hendri (2014) mengatakan pemuda merupakan suatu masa transisi dari masa remaja kepada masa dewasa. Pemuda telah dapat dikategorikan ke dalam angkatan kerja karena melihat umur pemuda yang digolongkan mulai dari 16 tahun menurut Undang-Undang nomor 40 tahun 2009 dan 18 tahun menurut Undang Undang Republik Indonesia Nomor 23 Tahun 2002 tentang perlindungan anak walaupun umur tersebut masih termasuk ke dalam umur sekolah.

Pengertian GBHN (1993) dalam Sumolang (2013), telah dijelaskan menjadi anak, remaja, dan pemuda, sedangkan ditinjau dari segi usia adalah sebagai berikut:

1) Usia 0-5 tahun di sebut balita

2) Usia 5-12 tahun di sebut anak usia sekolah

3) Usia 12-15 tahun di sebut remaja
4) Usia 15-30 tahun di sebut pemuda, dan

5) Usia 0-30 tahun di sebut generasi muda.

Pengelompokan yang dikatakan usia generasi muda pada umumnya yang dilihat dari berbagai segi. Mengenai persepsi tentang generasi muda sampai sekarang ini belum ada kesepakatan para ahli, namun pada dasarnya ada kesamaan mengenai pengertian generasi muda tersebut, yaitu beralihnya seseorang dari masa kanak-kanak menuju masa remaja atau muda dengan disertai perkembangan fisik Journal Volume II. No. 4. Tahun 2013 dan non fisik (jasmani, emosi, pola pikirannya dan sebagainya). Jadi generasi muda itu adalah sebagai generasi peralihan. Dan dalam pandangan orang tua belum dewasa generasi muda merupakan generasi penerus bangsa yang harus dipersiapkan dalam mencapai cita-cita bangsa, bila generasi muda telah dipercaya dan mempunyai rasa tanggung jawab yang tinggi dalam memperjuangkan amanah itu maka suatu bangsa tidak akan sia-sia dalam mendidik generasi tersebut, maka dari itu nilai yang dibangun dalam membentuk generasi muda ini adalah untuk menyiapkan penerus bangsa untuk melanjutkan perjuangan para pahlawan dalam Sumolang (2013).

\section{Rumusan Masalah}

Berdasarkan latar belakang di atas, yang menjadi permasalahan dalam penelitian adalah bagaimana persepsi pemuda untuk mengetahui dan melakukan kegiatan usaha tani kelapa di Desa Kauditan II?

\section{Tujuan Penelitian}

Penelitian ini bertujuan mengetahui bagaimana persepsi pemuda untuk mengetahui dan melakukan kegiatan usaha tani kelapa di Desa Kauditan II, penelitian ini dapat bermanfaat memberikan informasi kepada pihak-pihak terkait bagaimana pentingnya usaha tani dan dapat dijadikan informasi bagaimana pandangan pemuda terhadap kegiatan usaha tani kelapa di Desa Kauditan II, Kecamatan Kauditan, Kabupaten Minahasa Utara.

\section{Manfaat Penelitian}

Penelitian ini dapat bermanfaat memberikan informasi kepada pihak-pihak terkait bagaimana pentingnya usaha tani dan dapat dijadikan informasi bagaimana pandangan pemuda terhadap kegiatan usaha tani kelapa di Desa Kauditan II, Kecamatan Kauditan, Kabupaten Minahasa Utara. 


\section{METODE PENELITIAN}

\section{Waktu dan Tempat Penelitian}

Penelitian ini di laksanakan di Desa Kauditan II Kecamatan Kauditan, Kabupaten Minahasa Utara. Pemilihan lokasi dalam penelitian ini dipilih secara sengaja berdasarkan pertimbangan bahwa desa tersebut memiliki lahan pertanian dan jumlah pemuda yang ada didesa tersebut dapat mewakili objek penelitian ini. Waktu penelitian berlangsung selama enam bulan yaitu bulan Juli sampai bulan Desember 2019, yang dimulai dari persiapan, pengambilan data, sampai dengan laporan hasil penelitian.

\section{Pengambilan Sampel}

Data yang diperlukan dalam penelitian ini yaitu data primer dan data sekunder. Data primer diperoleh melalui wawancara dengan pemuda yang menjadi sampel dalam penelitian ini. Wawancara dilakukan dengan menggunakan daftar pertanyaan yang telah disiapkan terlebih dahulu. pertanyaan terdiri dari persepsi pemuda terhadap kegiatan usahatani kelapa. Data sekunder diperoleh melalui dokumen dan hasil penelitian kepustakaan serta data dan informasi yang berada di Desa Kauditan II kecamatan kauditan. Dalam penelitian yang menadi responden adalah semua pemuda yang orang tuanya berusahatani kelapa.

\section{Konsep Pengukuran Variabel}

A. Karakteristik Pemuda di Desa Kauditan II Kecamatan Kauditan

a. Nama yaitu dari pemuda di Desa Kauditan II Kecamatan Kauditan.

b. Umur yaitu usia dari pemuda 15-30 tahun.

c. Pendidikan yaitu yang ditetapkan berdasarkan tingkat pendidikanya mulai SD, SMP, SMA, hingga sarjana.

B. Persepsi Generasi muda

Persepsi pemuda yang di ukur dengan menggunkan kusioner, dan juga proses dalam kegiatan berusaha tani :
a) Pembibitan
b) Pengolahan Tanah
c) Penanaman dan Pemeliharaan
d) Panen
e) Paskah Panen

\section{Metode Analisis Data}

Tahap analisis data bertujuan untuk mengetahui persepsi Pemuda terhadap kegiatan usahatani kelapa di Desa Kauditan II. Teknik analisis data yang digunakan dalam penelitian data ini adalah teknik analisis dan deskriptif dengan menggunakan pengukuran skala likert (tabel check list). Jumlah pertanyaan yaitu (10) dengan responden yaitu (37) setiap jawaban dihubungkan dengan bentuk pernyataan dan dukungan yang diungkapkan dengan kata-kata dan dikategori-kan sebagai berikut:

$\begin{array}{lll}\text { SS } & \text { : Sangat Setuju } & \text { skor: } 5 \\ \text { S } & \text { : Setuju } & \text { skor: } 4 \\ \text { RR } & \text { : Ragu-ragu } & \text { skor: } 3 \\ \text { TS } & \text { : Tidak Setuju } & \text { skor: } 2 \\ \text { STS } & \text { : Sangat tidak setuju } & \text { skor: } 1 \\ \text { Dengan perhitungan skor : } & \end{array}$

Jumlah skor tiap Kriterium = Capaian Skor terendah $\mathrm{x}$ Jumlah Responden

$$
\begin{aligned}
& \text { S5 }=5 \times 37=185 \\
& \text { S4 }=4 \times 37=148 \\
& \text { S3 }=3 \times 37=111 \\
& \text { S2 }=2 \times 37=74 \\
& \text { S1 }=1 \times 37=37 \\
& \text { Jumlah skor tertinggi }=185, \text { dan jumlah }
\end{aligned}
$$
skor terendah $=37$. Dengan interprestasi nilai:

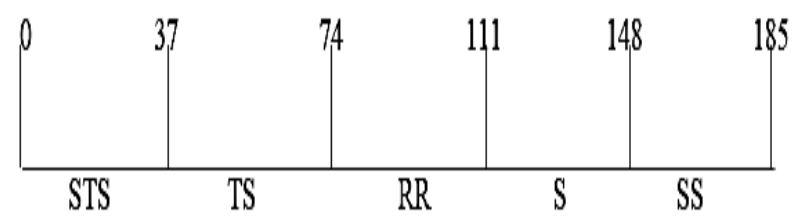

Cara perhitungan skor keseluruhan untuk mengetahui persepsi generasi muda terhadap kegiatan usaha tani kelapa yaitu:

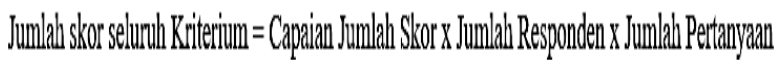

$\mathrm{S}_{5}=5 \times 37 \times 10=1.850$

$\mathrm{S}_{4}=4 \times 37 \times 10=1.480$

$\mathrm{S}_{3}=3 \times 37 \times 10=1.110$

$\mathrm{S}_{2}=2 \times 37 \times 10=740$

$\mathrm{S}_{1}=1 \times 37 \times 10=370$

Jumlah skor ideal untuk keseluruhan pertanyaan tinggi $=1.850$,

Jumlah skor terendah $=370$

Dengan interprestasi nilai :

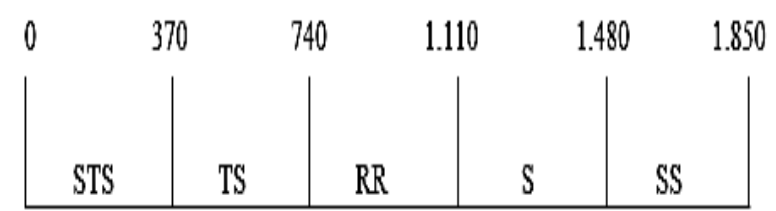


Analisis data yang digunakan merupakan analisi deskriptif yang dianalisis dengan menggunakan skala likert (likert scale) dimana menurut Ridwan (2008) sebagai berikut:

Persepsi Generasi muda $=\frac{\text { Jumlsh Skor Hasil Pengumpulan Data }}{\text { Jumlah Skor Ideal (tertinggi) }} \times 100 \%$

Dengan Interpretasi nilai :

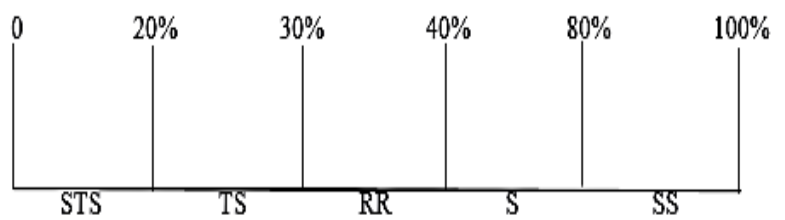

Angka 0\%-20\% = Sangat Tidak Setuju

Angka $21 \%-40 \%=$ Tidak Setuju

Angka $41 \%-60 \%=$ Ragu - Ragu

Angka $61 \%-80 \%=$ Setuju

Angka $81 \%-100 \%=$ Sangat Setuju

\section{HASIL DAN PEMBAHASAN}

\section{Gambaran Umum Lokasi Penelitian}

Desa Kauditan II adalah merupakan salah satu desa yang berada di wilayah kecamatan Kauditan dan tepatnya berada di ibukota kecamatan Kauditan, luas wilayah $1007 \mathrm{Ha}$ dan jumlah jaga yaitu 13 (tiga belas) dengan batas - batas wilayah sebagai berikut :

1. Sebelah Utara berbatasan dengan Desa Kauditan I Kecamatan Kauditan

2. Sebelah Timur berbatasan dengan Desa Tontalete Kecamatan Kema.

3. Sebelah selatan berbatasan dengan Desa Kauditan I Kecamatan Kauditan dan Desa Tontalete Kecamatan Kema.

4. Sebelah Barat berbatasan dengan Desa Kauditan I Kecamatan Kauditan.

Jumlah penduduk yang ada Desa Kauditan II adalah sebanyak 2.658 jiwa dengan Jumlah keluarga petani kelapa $24 \mathrm{KK}$, sedangkan untuk jumlah pemuda laki-laki 345 jiwa dan perempuan 317 jiwa.

\section{Karakteristik Responden}

Karakteristik Responden Menurut Tingkat Umur

Responden dalam penelitian ini mencakup pemuda yang bertempat tinggal di Desa Kauditan II, responden yang akan diambil adalah orang tuanya adalah petani kelapa dan tinggal di Desa Kauditan II Kecamatan Kauditan terdiri dari berbagai tingkat usia. Usia responden yang telah ditentukan adalah seorang pemuda yang berumur 15 tahun sampai 30 tahun, pengelompokan umur responden dilakukan dalam upaya mempermudah proses pengolahan data. Kelompok umur dibagi menjadi 2 kelompok umur yaitu 15 tahun sampai 22 tahun, 23 tahun sampai 30 tahun. Gambaran mengenai kelompok umur responden dapat dilihat dalam Tabel 1.

\begin{tabular}{lccr}
\multicolumn{4}{c}{ Tabel 1. Karakteristik Responden Menurut Tingkat Umur } \\
\hline No & Umur (Tahun) & $\begin{array}{c}\text { Jumlah Responden } \\
\text { (Pemuda) }\end{array}$ & Persentase (\%) \\
\hline 1. & $15-22$ & 18 & 48.64 \\
2. & $23-30$ & 19 & 51.36 \\
\hline \multicolumn{4}{l}{ Sumber : Kantor Desa Kauditan II, 2019 }
\end{tabular}

Tabel 1 menunjukkan bahwa umur responden yaitu dari 15 tahun sampai dengan 30 tahun yang disebut sebagai pemuda. Umur responden pada interval 23 sampai dengan 30 tahun memiliki nilai persentase nilai yang terbanyak atau merupakan umur responden terbanyak dengan persentase $51.36 \%$ dengan responden sebanyak 19 0rang, dan umur responden 15 tahun sampai 22 tahun memiliki nilai persentase $48.64 \%$. umur pemuda dikategorikan ke dalam angkatan kerja dan ada berbagai faktor yang menyebabkan pemuda memasuki angakatan kerja salah satunya sudah tidak bersekolah lagi atau putus sekolah karena faktor ekonomi dengan kondisi tersebut terpaksa harus bekerja atau mencari pekerjaan dan seseorang yang telah menamatkan jenjang pendidikan tertentu akan bekerja atau mencari pekerjaan.

\section{Karakteristik Responden Menurut Tingkat Pendidikan}

Semakin tinggi tingkat pendidikan seseorang semakin banyak pula pengetahuan atau wawasan yang dimiliki, baik itu menciptakan, menerapkan teknologi baru serta inovasi-inovasi yang baru. Dari hasil penelitian yang dilakukan, tingkat pendidikan responden yaitu dari SD, SMP, SMA, S1. Hal ini dapat dilihat pada Tabel 2.

\begin{tabular}{llcr}
\multicolumn{4}{c}{ Tabel 2. Karakteristik Responden Menurut Tingkat Pendidikan } \\
\hline No & Tingkat Pendidikan & $\begin{array}{c}\text { Jumlah Responden } \\
\text { (Pemuda) }\end{array}$ & $\begin{array}{c}\text { Persentase } \\
(\%)\end{array}$ \\
\hline 1. & SD & 1 & 2.7 \\
2. & SMP & 4 & 10.8 \\
3. & SMA & 25 & 67.6 \\
4. & Perguruan Tinggi & 7 & 18.9 \\
& (Mahasiswa) & 37 & 100 \\
\hline \multicolumn{4}{l}{ Jumlah }
\end{tabular}


Tabel 2 menunjukkan bahwa perolehan persentase dari masing-masing tingkat pendidikan yaitu SMA 64.9\% atau dengan jumlah responden 25 pemuda dan merupakan persentase responden terbanyak, dan persentase terbanyak kedua perguruan tinggi sebesar $18.9 \%$ dengan jumlah responden 7 pemuda, persentase SMP sebesar $10.8 \%$ dengan responden 4 pemuda, pada tingkat SD sebesar $2.7 \%$ dengan jumlah responden 1 pemuda. Hal ini menunjukkan bahwa dalam penentuan responden tidak ditentukan tingkat pendidikannya dan juga menunjukkan bahwa pentingnya persepsi seorang pemuda terhadap kegiatan usahatani kelapa dari sudut pandang yang berbeda.

\section{Persepsi Pemuda Terhadap Pembibitan}

\section{Persepsi Pemuda Mengetahui Pembibitan Pada Tanaman Kelapa}

Pembibitan kelapa mempunyai peranan penting dalam keberhasilan pengembangan kelapa karena dapat menjadi indikator banyaknya produksi. Hasil penelitian dari penilaian pada responden mengenai persepsi pemuda untuk mengetahui pembibitan tanaman kelapa dapat dilihat pada Tabel 3.

Tabel 3. Persepsi Pemuda Ingin Mengetahui Pembibitan Pada

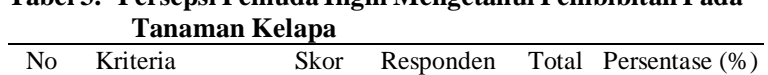

\begin{tabular}{llcccc}
\hline No & Kriteria & Skor & Responden & $\begin{array}{c}\text { Total } \\
\text { Skor }\end{array}$ & Persentase (\%) \\
\hline 1. & Sangat Setuju & 5 & 1 & 5 & 4.16 \\
2. & Setuju & 4 & 19 & 76 & 63.33 \\
3. & Ragu-ragu & 3 & 7 & 21 & 17.5 \\
4. & Tidak Setuju & 2 & 9 & 18 & 15 \\
5. & Sangat Tidak & 1 & 0 & 0 & 0 \\
& Setuju & \multicolumn{5}{c}{37} \\
\hline \multicolumn{5}{l}{ Jumlah } \\
\hline \multicolumn{5}{l}{ Sumber : Olahan Data Primer Desa Kauditan II }
\end{tabular}

Tabel 3 menunjukkan bahwa persentase terbesar adalah 73,28 persen dengan skor penilaian 96. Pemuda setuju untuk mengetahui bagaimana pembibitan pada tanaman kelapa karena untuk menghasilkan tanaman yang subur dan sehat. Keuntungan yang diperoleh dari bibit yang subur dan sehat yaitu menghasilkan tanaman yang berbuah lebih awal dan berproduksi tinggi.

\section{Persepsi Pemuda Ingin Melakukan Pembibitan Pada Tanaman Kelapa}

Hasil penelitian dari penilaian pada responden mengenai persepsi pemuda setuju melakukan pembibitan pada tanaman kelapa dapat dilihat dalam Tabel 4.

\begin{tabular}{llcccc}
\multicolumn{6}{l}{ Tabel 4. Persepsi Pemuda Ingin Melakukan Pembibitan } \\
\hline No & Kriteria & Skor & Responden & $\begin{array}{c}\text { Total } \\
\text { Skor }\end{array}$ & Persentase (\%) \\
& & & & 5 & 4.16 \\
\hline 6. & Sangat Setuju & 5 & 2 & 76 & 63.33 \\
7. & Setuju & 4 & 24 & 21 & 17.5 \\
8. & Ragu-ragu & 3 & 3 & 18 & 15 \\
9. & Tidak Setuju & 2 & 8 & 0 & 0 \\
10. & Sangat Tidak & 1 & 0 & & \\
& Setuju & & & 120 & 100 \\
\hline
\end{tabular}

Sumber : Olahan Data Primer Desa Kauditan II

Tabel 4 menunjukkan bahwa kriteria setuju persentase $63.33 \%$ dan skor 76 adalah penilaian tertinggi bahwa pemuda setuju untuk melakukan pembibitan pada tanaman kelapa karena pembibitan merupakan awal kegiatan lapangan yang harus dimulai setahun sebelum penanaman dilapangan dan merupakan faktor utama yang paling menentukan produksi perhektar tanaman dan termasuk sebagai upaya strategis dalam mempersiapkan tanaman jangka panjang.

\section{Persepsi Pemuda Terhadap Pengolahan Tanah}

\section{Persepsi Pemuda Mengetahui Pengolahan Tanah Pada Tanaman Kelapa}

Hasil penelitian dari penilaian pada responden mengenai persepsi pemuda setuju ingin mengetahui pengolahan tanaman kelapa dapat dilihat pada Tabel 5.

Tabel 5. Persepsi Pemuda Mengetahui Pengolahan Tanah Pada Tanaman Kelapa

\begin{tabular}{llcccc}
\hline No & Kriteria & Skor & Responden & $\begin{array}{c}\text { Total } \\
\text { Skor }\end{array}$ & Persentase (\%) \\
\hline 1. & Sangat Setuju & 5 & 2 & 10 & 7.75 \\
2. & Setuju & 4 & 22 & 88 & 68.21 \\
3. & Ragu-ragu & 3 & 5 & 15 & 11.65 \\
4. & Tidak Setuju & 2 & 8 & 16 & 12.4 \\
5. & Sangat Tidak & 1 & 0 & 0 & 0 \\
& Setuju \\
\hline \multicolumn{5}{l}{ Jumlah } \\
\hline \multicolumn{5}{l}{ Sumber : Olahan Data Primer Desa Kauditan II } \\
\multicolumn{5}{l}{129} \\
\end{tabular}

Tabel 5 menunjukkan bahwa persentase $68.21 \%$ skor 88. Pemuda setuu mengetahui pengolahan tanah pada tanaman kelapa yang merupakan komponen lahan yang utama, karena dengan tanah yang peresapan air yang baik dapat membantu pertumbuhan tanaman kelapa.

\section{Persepsi Pemuda Melakukan Pengolahan Tanah Untuk Tanaman Kelapa \\ Hasil penelitian dari penilaian pada responden mengenai persepsi pemuda setuju ingin melakukan pengolahan tanah dapat dilihat pada Tabel 6.}


Tabel 6. Persepsi Pemuda setuju ingin Melakukan Pengolahan Tanah Untuk Tanaman Kelapa

\begin{tabular}{llcccc}
\hline No & Kriteria & Skor & Responden & $\begin{array}{c}\text { Total } \\
\text { Skor }\end{array}$ & Persentase (\%) \\
\hline 6. & Sangat Setuju & 5 & 1 & 5 & 4.03 \\
7. & Setuju & 4 & 20 & 80 & 64.51 \\
8. & Ragu-ragu & 3 & 7 & 21 & 16.91 \\
9. & Tidak Setuju & 2 & 8 & 18 & 13.11 \\
10. & Sangat Tidak & 1 & 0 & 0 & 0 \\
& Setuju & & & & 100 \\
\hline & Jumlah & & & \\
\hline
\end{tabular}

Sumber : Olahan Data Primer Desa Kauditan II

Tabel 6 menunjukkan bahwa perolehan skor penilaian 80 dengan persentase $64.51 \%$. Pemuda sangat setuju melakukan pengolahan tanah karena dilihat dari lahan yang dimiliki memiliki permukaan air tanah yang cukup dalam, memenuhi kebutuhan pertumbuhan bagi perakaran. lahan memiliki komponen tanah yang memenuhi syarat.

\section{Persepsi Pemuda Terhadap Penanaman Dan Pemeliharaan Tanaman Kelapa}

\section{Persepsi Pemuda Setuju Mengetahui Penanaman Dan Pemeliharaan Tanaman Kelapa}

Hasil penelitian dari penilaian pada responden mengenai persepsi pemuda untuk setuju mengetahui penanaman dan pemeliharaan tanaman kelapa dapat dilihat pada Tabel 7.

Tabel 7. Persepsi Pemuda Mengetahui Penanaman Dan Pemeliharaan

\begin{tabular}{llcccc}
\multicolumn{6}{c}{ Pemeliharaan } \\
\hline No & $\begin{array}{l}\text { Tingkat } \\
\text { Pendidikan }\end{array}$ & Skor & Responden & $\begin{array}{l}\text { Total } \\
\text { Skor }\end{array}$ & Persentase (\%) \\
\hline 1. & Sangat Setuju & 5 & 1 & 5 & 403 \\
2. & Setuju & 4 & 20 & 80 & 64.51 \\
3. & Ragu-ragu & 3 & 7 & 21 & 16.91 \\
4. & Tidak Setuju & 2 & 8 & 18 & 13.11 \\
5. & Sangat Tidak & 1 & 0 & 0 & 0 \\
& Setuju & \multicolumn{5}{c}{37} \\
\hline & Jumlah \\
\hline Sumber : Olahan Data Primer Desa Kauditan II
\end{tabular}

Tabel 7 menunjukkan bahwa skor penilaian yang diperoleh pada kriteria sangat setuju yaitu 10 dan persentase $7.87 \%$. pemuda sangat setuju mengetahui karena proses penanaman dan pemeliharaan memerlukan komitmen dan kesabaran sehingga dapat dipastikan pertumbuhan dan produksi kelapa menjadi lebih optimal. Kriteria setuju skor penilaian 84 dan persentase $66.14 \%$. pemuda setuju mengetahui karena keterbatasan pengetahuan dan informasi dalam pemeliharaan tanaman kelapa menjadi kendala untuk peningkatan kualitas tanaman. Kriteria ragu- ragu dengan skor penilaian 15 dan persentase $11.81 \%$. Pemuda ragu-ragu untuk mengetahui karena tidak memiliki lahan. Kriteria tidak setuju dengan skor penilaian 18 dan persentase $14.17 \%$. pemuda tidak setuju mengetahui penanaman dan pemeliharaan karena tidak ada jaminan tergantung pada faktor alam dan lingkungan untuk pertumbuhan tanaman kelapa.

\section{Persepsi Pemuda Melakukan Penanaman Dan Pemeliharaan Tanaman Kelapa}

Hasil penelitian dari penilaian pada responden mengenai persepsi pemuda setuju melakukan penanaman dan pemeliharaan pada tanaman kelapa dapat dilihat pada Tabel 8.

Tabel 8. Persepsi Pemuda Setuju Ingin Melakukan Penanaman Dan Pemeliharaan

\begin{tabular}{|c|c|c|c|c|c|}
\hline No & $\begin{array}{l}\text { Tingkat } \\
\text { Pendidikan }\end{array}$ & Skor & Responden & $\begin{array}{l}\text { Total } \\
\text { Skor }\end{array}$ & $\begin{array}{c}\text { Persentase } \\
(\%)\end{array}$ \\
\hline 1. & Sangat Setuju & 5 & 1 & 5 & 403 \\
\hline 2. & Setuju & 4 & 19 & 76 & 61.29 \\
\hline 3. & Ragu-ragu & 3 & 9 & 27 & 21.27 \\
\hline 4. & Tidak Setuju & 2 & 8 & 16 & 12.9 \\
\hline 5. & $\begin{array}{l}\text { Sangat Tidak } \\
\text { Setuju }\end{array}$ & 1 & 0 & 0 & 0 \\
\hline & Jumlah & & 37 & 124 & 100 \\
\hline
\end{tabular}

Tabel 8 menunjukkan bahwa skor penilaian yang diperoleh pada kriteria setuju skor 76 dan persentase $61.29 \%$. \% . pemuda sangat setuju ingin melakukan karena memiliki lahan. Penanaman dan pemeliharaan yang benar dapat terhindar dari serangan hama.

\section{Persepsi Pemuda Pada Panen Tanaman Kelapa}

\section{Persepsi Pemuda Mengetahui Cara Panen Tanaman Kelapa}

Hasil penelitian dari penilaian pada responden mengenai persepsi pemuda setuju mengetahui cara panen tanaman kelapa dapat dilihat pada Tabel 9.

Tabel 9. Persepsi Pemuda Mengetahui Cara Panen Pada Tanaman Kelapa

\begin{tabular}{llcccc}
\hline No & $\begin{array}{l}\text { Tingkat } \\
\text { Pendidikan }\end{array}$ & Skor & Responden & $\begin{array}{l}\text { Total } \\
\text { Skor }\end{array}$ & Persentase (\%) \\
\hline 1. & Sangat Setuju & 5 & 1 & 5 & 3.96 \\
2. & Setuju & 4 & 21 & 84 & 66.66 \\
3. & Ragu-ragu & 3 & 7 & 21 & 16.66 \\
4. & Tidak Setuju & 2 & 8 & 16 & 12.6 \\
5. & Sangat Tidak & 1 & 0 & 0 & 0 \\
& Setuju & \multicolumn{5}{c}{126} \\
\hline & Jumlah \\
\hline \multicolumn{5}{l}{ Sumber : Olahan Data Primer Desa Kauditan II } \\
\hline
\end{tabular}


Tabel 9 menunjukkan bahwa persentase penilaian pada kriteria sangat setuju yaitu $3.96 \%$ dengan skor 5. Pemuda sangat setuju mengetahui panen pada tanaman kelapa karena seorang pemanen harus mengetahui bagaimana menjaga kondisi, jumlah pelepah dan tingkat kematangan buah kelapa. Kriteria setuju persentase $66.66 \%$ dengan skor 84 . Pemuda setuju mengetahui panen pada tanaman kelapa karena pentingnya memperhatikan kematangan buah kelapa dan sesuai kebutuhannya. Kriteria ragu-ragu persentase $16.66 \%$ dengan skor 21. Pemuda ragu-ragu untuk mengetahui cara panen karena tidak memiliki tanaman kelapa untuk dipanen. Kriteria tidak setuju skor 16 dengan persentase penilaian $12.6 \%$. pemuda tidak setuju untuk mengetahui cara panen karena untuk memanen bisa menggunakan tenaga kerja sebagai pemanen.

\section{Persepsi Pemuda Melakukan Panen Pada Tanaman Kelapa}

Hasil penelitian dari penilaian pada responden mengenai persepsi pemuda setuju ingin melakukan panen pada tanaman kelapa dapat dilihat pada Tabel 10.

Tabel 10. Persepsi Pemuda Ingin Melakukan Panen Pada Tanaman Kelapa

\begin{tabular}{llcccc}
\hline No & $\begin{array}{l}\text { Tingkat } \\
\text { Pendidikan }\end{array}$ & Skor & Responden & $\begin{array}{c}\text { Total } \\
\text { Skor }\end{array}$ & Persentase (\%) \\
\hline 1. & Sangat Setuju & 5 & 1 & 5 & 3.96 \\
2. & Setuju & 4 & 21 & 84 & 66.66 \\
3. & Ragu-ragu & 3 & 7 & 21 & 16.66 \\
4. & Tidak Setuju & 2 & 8 & 16 & 12.6 \\
5. & Sangat Tidak & 1 & 0 & 0 & 0 \\
& Setuju & & & & \\
\hline & Jumlah & & 37 & 126 & 100 \\
\hline
\end{tabular}

Sumber : Olahan Data Primer Desa Kauditan II

Tabel 10 menunjukkan bahwa persentase penilaian pada kriteria $53.57 \%$ dengan skor 60 . Pemuda setuju ingin melakukan panen pada tanaman kelapa karena cara pemanen kelapa disesuaikan dengan kondisi masing-masing misalnya buah kelapa dibiarkan jatuh dan juga buah kelapa dapat dipanjat dan juga memiliki tanaman kelapa yang siap dipanen. karena memenuhi tuntutan kebutuhan ekonomi dan memiliki keuntungan untuk hasil olahan buah kelapa.

\section{Persepsi Pemuda Pada Pascapanen Tanaman Kelapa}

\section{Persepsi Pemuda Mengetahui Pascapanen Pada} Tanaman Kelapa

Hasil penelitian dari penilaian pada responden mengenai persepsi pemuda setuju ingin Mengetahui pascapanen pada tanaman kelapa dapat dilihat pada Tabel 11.
Tabel 11. Persepsi Pemuda Setuju Ingin Mengetahui Pascapanen Pada Tanaman Kelapa

\begin{tabular}{llcccc}
\hline No & $\begin{array}{l}\text { Tingkat } \\
\text { Pendidikan }\end{array}$ & Skor & Responden & $\begin{array}{c}\text { Total } \\
\text { Skor }\end{array}$ & Persentase (\%) \\
\hline 1. & Sangat Setuju & 5 & 5 & 25 & 17.48 \\
2. & Setuju & 4 & 25 & 104 & 72.72 \\
3. & Ragu-ragu & 3 & 2 & 6 & 4.19 \\
4. & Tidak Setuju & 2 & 4 & 8 & 5.59 \\
5. & Sangat Tidak & 1 & 0 & 0 & 0 \\
& Setuju & \multicolumn{5}{c}{143} \\
\hline \multicolumn{5}{l}{ Jumlah } \\
\hline \multicolumn{5}{l}{ Sumber: Olahan Data Primer Desa Kauditan II }
\end{tabular}

Tabel 11 menunjukkan bahwa Pemuda setuju untuk mengetahui pascapanen karena kegiatan pascapanen meliputi kegiatan penyortiran dan penggolangan, penyimpana dan pengolahan awal yang akan mengasilkan suatu nilai pada buah kelapa karena hampir semua bagian dari buah kelapa bisa dimanfaatkan. Pada kriteria setuju perolehan skor penilaian 100 dengan persentase $72.72 \%$. Pemuda setuju mengetahui pascapanen karena hampir semua bagian dari buah kelapa bisa dimanfaatkan.

\section{Persepsi Pemuda Ingin Melakukan Pascapanen Tanaman Kelapa}

Hasil penelitian dari penilaian pada responden mengenai persepsi pemuda setuju ingin melakukan pascapanen pada tanaman kelapa dapat dilihat pada Tabel 12.

Tabel 12. Pemuda Setuju Ingin Melakukan Pascapanen Pada

\begin{tabular}{llcccc}
\multicolumn{5}{c}{ Tanaman Kelapa } \\
\hline No & $\begin{array}{l}\text { Tingkat } \\
\text { Pendidikan }\end{array}$ & Skor & Responden & $\begin{array}{c}\text { Total } \\
\text { Skor }\end{array}$ & $\begin{array}{c}\text { Persentase } \\
(\%)\end{array}$ \\
\hline 1. & Sangat Setuju & 5 & 3 & 15 & 11.27 \\
2. & Setuju & 4 & 22 & 88 & 66.16 \\
3. & Ragu-ragu & 3 & 6 & 18 & 13.53 \\
4. & Tidak Setuju & 2 & 6 & 12 & 9.02 \\
5. & Sangat Tidak & 1 & 0 & 0 & 0 \\
& Setuju & & & & \\
\hline & Jumlah & 37 & 133 & 100 \\
\hline
\end{tabular}

Sumber : Olahan Data Primer Desa Kauditan II

Tabel 12 menunjukkan bahwa penilaian pada kriteria setuju yaitu persentase $66.16 \%$ dengan skor 88. Pemuda setuju ingin melakukan pascapanen karena seluruh bagian dari buah kelapa dapat dimanfaatkan.

\section{Rekapitulasi Hasil Dari Penelitian Persepsi Pemuda Terhadap Kegiatan Usahatani Kelapa \\ Di Desa Kauditan II Kecamatan Kauditan}

Rekapitulasi hasil dari penelitian persepsi pemuda terhadap kegiatan usahatani kelapa di Desa Kauditan II Kecamatan Kauditan. Total skor yang diperoleh dari penilaian pada setiap indikator 1.263. hal ini menggambarkan bahwa persepsi pemuda berada pada kriteria atau interval setuju dengan interval kelas $1.110-1480$. 


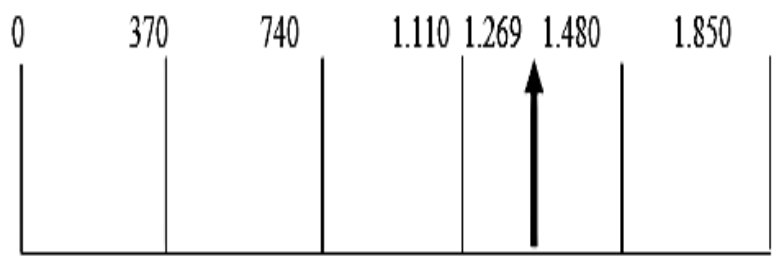

$\begin{array}{lllll}\text { STS } & \text { TS } & \text { RR } & S & \text { SS }\end{array}$

Tingkat sikap $=\frac{1269}{1850} \times 100 \%=68,59 \%$

Dengan interpretasi nilai:

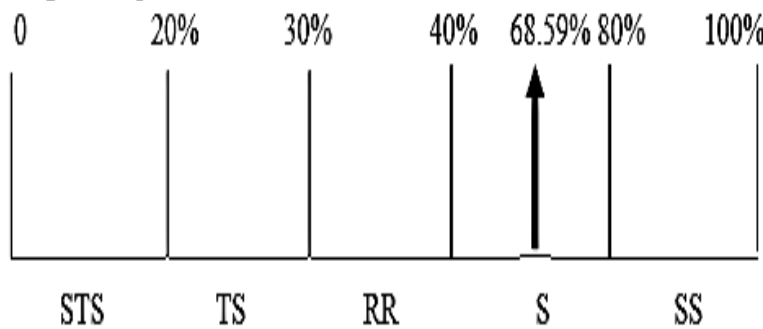

Tingkat sikap persepsi pemuda dengan persentase nilai $68.59 \%$ menggambarkan bahwa pemuda setuju untuk mengetahui dan melakukan kegiatan usahatani kelapa yang ada di Desa Kauditan II Kecamatan Kauditan. Persepsi pemuda masih tergolong baik. Intinya pemuda masih tertarik dibidang pertanian yaitu usahatani kelapa, tingkat ingin tahu dari pemuda memiliki persentase yang tinggi dan hal ini menunjukkan persepsi pemuda terhadap kegiatan usahatani kelapa adalah baik. Pemuda setuju untuk mengetahui dan ingin melakukan kegiatan usahatani kelapa karena semua bagian dari tanaman kelapa dapat dimanfaatkan.

\section{KESIMPULAN DAN SARAN}

\section{Kesimpulan}

Hasil penelitian yang dilakukan mengenai persepsi pemuda terhadap kegiatan usahatani kelapa di Desa Kauditan II kecamatan Kauditan menunjukkan bahwa pemuda setuju untuk mengetahui dan ingin melakukan kegiatan usahatani kelapa di Desa Kauditan II Kecamatan. Pernyataan pemuda untuk mengetahui pascapanen cenderung lebih tinggi yaitu setuju karena pekerjaan pascapanen dianggap lebih mudah dibandingkan dengan kegiatan usahatani lainnya, sedangkan skor terendah dari pernyataan pemuda ingin melakukan panen pada tanaman kelapa karena pemuda tidak ingin melakukan kegiatan panjat kelapa yang membutuhkan teknik khusus untuk pemanjatan pohon kelapa.

\section{Saran}

Disarankan kepada Pemerintah Daerah Minahasa Utara untuk melakukan pelatihan pascapanen usahatani kelapa kepada pemuda. Dan Pemerintah harus mencari cara memanjat kelapa yang efisien untuk menutupi kekurangan tenaga kerja pada saat pemanjatan kelapa.

\section{DAFTAR PUSTAKA}

Anonimous. Data Desa Kauditan, 2019. Statistika Pendudukan, Kauditan.

Firdaus, M. 2015. Manajemen Agribisnis. Diterbitkan oleh PT Bumi Aksara Jakarta.

Gibson,1989. Faktor-faktor yang mempengaruhi persepsi. (www. duniapsikiologi.com).

Hendri, M. 2014. Persepsi pemuda pencari kerja terhadap pekerjaan sektor pertanian dan pilihan pekerjaan di Desa Cihideung Udik Kecamatan Crampea Kabupaten Bogor. Institut pertanian Bogor.

Heriyanto, 2014. Persepsi masyarakat terhadap kualits pelayanan publik pada bagian administrasi kesejahteraan rakyat pemerintah Kabupaten Gunung Kidul DIY. Universitas Negeri Yogyakarta.

Rachman, M. 2013. Persepsi masyarakat terhadap keberadaan peternak babi kampung ketimbang Kelurahan Paccerakkang Kecamatan Biring Kanaya Makassar. 
Setiawan, A. 2010. Identifikasi faktor-faktor yang mempengaruhi persepsi masyarakat dalam pemilihan partai politik di Daerah rawan konflik melalui modal persamaan struktural MPS. Institut pertanian Bogor.

Sumolang, M. 2013. Peranan internet terhadap generasi muda di Desa Tounelet Kecamatan Langowan Barat. Universitas Sam Ratulangi Manado.
Warsana, 2007. Analisis efisiensi dan keuntungan usaha tani jagung, studi di Kecamatan Randu Blatung Kabupaten Blora, Universitas Dipenogoro Semarang. 